\title{
Infrastructure development and the National Rural Employment Guarantee Scheme: Evidence from Bankura, West Bengal
}

\author{
Jitendra Roy and Arjun S. Bedi*
}

\section{Introduction}

The immediate goal of the National Rural Employment Guarantee Scheme (NREGS) is to ensure a social safety net for vulnerable groups by providing a fall-back source of employment when other alternatives are scarce. However, its long-term goals are to create durable rural assets and infrastructure which meet local needs and help address chronic poverty and to foster a model of governance based on the principles of grass-root democracy and transparency (Ministry of Rural Development, 2008). While several papers have examined pertinent aspects of the functioning of the programme, such as targeting (Jha et al., 2009), impact on consumption (Ravi and Engler, 2009) and various implementation issues including corruption (Rai, 2008; Institute of Applied Manpower Research, 2008) there is limited work on the quality and upkeep of the infrastructure built through the programme and indeed whether the constructed projects meet local needs. ${ }^{1}$

The work that does exist paints a troublesome picture. For instance, in their work on Jharkhand, Bhatia and Dreze (2006) observe that "most of the works had remained incomplete, and were in danger of being washed away in the coming monsoon. In other cases, the work had been completed but its productive value was doubtful". In their review article Ambasta et al. (2008) also comment on the poor quality of the assets built through NREGA. In a study on Madhya Pradesh, Rai (2008) reports that innumerable tree plantation projects were executed under NREGS without a single surviving sapling or plant. A more detailed micro-level analysis of the sustainability of assets created through NREGS is offered by Action for Food Production (2009). This study funded by UNDP and supported by the Ministry of Rural Development (MoRD) is based on a micro-level assessment of 37 projects located in 10 Gram Panchayats in Jharkhand's Gumla district. The analysis reveals that about half the projects are incomplete even though some started in 2006-07 and that there is no maintenance system. The authors go on to suggest that this is due to a gap between local needs and the selected projects due to limited participation of the Gram Sabha in project selection and design - "proposal of any intervention

\footnotetext{
* Roy (iitendr roy@,rediffmail.com), Government of West Bengal; Bedi (bedi@iss.nl), International Institute of Social Studies (ISS), Erasmus University Rotterdam, The Netherlands. We thank the ISS for a grant that supported data collection.

1 See www.nrega.net which contains an exhaustive repository of more than 800 NREGA related documents including newspaper articles, commissioned reports, working papers and journal articles.
} 
placed by the [gram panchayat] members in gram sabha is normally accepted" (p. 26). ${ }^{2}$ Clearly, a prerequisite, if NREGS is to live up to its long-term goal of creating durable assets, is to examine whether the infrastructure projects built through it match local needs and whether the assets are well constructed and maintained.

Accordingly, this paper provides a micro level assessment of the infrastructure projects implemented through NREGS in West Bengal's Bankura district. ${ }^{3}$ Broadly, we examine two aspects of NREGS with regard to asset creation. First, the extent to which the selected projects meet local needs. This is captured by gauging community participation in project selection, location, scale and design. Second, we provide an assessment of the operational and physical condition of the projects and the role of community participation in influencing these outcomes. The study is based on primary data collected in July 2011, from a district-level representative sample of 82 completed projects of various types, executed during the financial years 2008-09 and 2010-2011 in 23 villages located in 10 Gram Panchayats. Apart from the inherent merit of analysing these issues, the study is motivated by a desire to place discussions about the usefulness of a decentralized approach to building rural infrastructure on a stronger empirical footing.

The following section of the paper outlines our sampling approach while Sections III and IV contain results and Section V concludes the paper.

\section{Sampling and field work}

The sampling strategy developed for the paper was designed to be representative of the district as a whole. Based on a hydro-geomorphic zoning exercise of the district conducted between 1998 and 2002 by the State Water Investigation Directorate, West Bengal (see UNDP, District Human Development Report, 2007, p. 43) we divided the state's administrative blocks into three zones based on type of soil and water availability. ${ }^{4}$ Based on this classification, 86 Gram Panchayats (GPs) fell in Zone I, 57 in Zone II and 47 in Zone III. As per census 2001, these three zones accounted for 44, 30 and 26 percent of the district population respectively.

\footnotetext{
2 There is no dearth of newspaper columns and opinions on the futility of the scheme while at the same time there are reports of the innovative manner in which the scheme has been used. For instance, a civil servant in Bihar attracted attention for clubbing 'social forestry' with NREGS to address global warming and shrinking job opportunities through the idea of planting trees. See http://news.bbc.co.uk/2/hi/8257563.stm

3 Bankura was amongst the two hundred districts included in the first phase of the implementation of the employment guarantee scheme. It is amongst the state's poorer districts and according to UNDP, District Human Development Report (2007, p.8), the HDI ranking of Bankura is 11 th of 19 districts in West Bengal.

${ }^{4}$ Bankura's rural economy is heavily dependent on agriculture and livelihood strategies are determined by the type of soil and water availability in its different regions. The district is drought prone and topographically, it may be divided into three distinct regions - a hilly western region, undulating central region and alluvial plains in the east. The hilly region is characterized by large granite rocks, the central part by red laterite and eastern part by alluvial loamy soil (UNDP, DHDR, 2007: p.5). The western and central regions have low soil fertility while the eastern part has rich alluvial soil.
} 
Since the GPs are the main local bodies charged with implementing the NREGS we decided, on pragmatic grounds, to work with a 5 percent sample of GPs and select the number of GPs from each of the three zones on the basis of the population living in each zone. Thus, we selected 10 GPs for the survey with 4 from Zone I and 3 each from Zones II and III. Within each zone, the GPs to be surveyed were randomly selected (for a list of surveyed GPs see Table 1). ${ }^{5}$ Subsequently, we randomly selected 2 to 3 villages in each GP. For each of the selected villages we obtained a list of all the projects implemented during the financial years 2008-09, 2009-10 and 2010-11, a total of 1486 projects, and randomly drew a 5 percent sample which accounted for the increasing intensity of NREGA related activity over time (more projects from recent years) and the type of projects implemented. ${ }^{6}$ The final sample consisted of 82 projects spread over 23 villages and 10 GPs. The distribution by project type is provided in Table 2.

To gather information we used a structured questionnaire which was administered by a group of trained enumerators. Since the projects are supposed to cater collectively to local needs, for each of the 82 projects, information was obtained from a village respondent group (VRG) which consisted of individuals living in the catchment area of the project. ${ }^{7}$ Each of the projects was subjected to physical verification and structured interviews were also conducted with GP functionaries and with the concerned Programme Officers (PO)/Block Development Officers (BDO).

\section{Meeting local needs and preference targeting}

The National Rural Employment Guarantee Act (NREGA) envisages a decentralized 'bottom-up' approach to project selection and implementation. In this process, a pivotal role for both planning and implementation is entrusted to the Gram Panchayat (GP) - a body of elected representatives. The members of the GP are elected from several village constituencies (Gram Sansad) with each constituency electing one or two representatives. The gram panchayat members (GPM) are accountable to the Gram Sansad and the Gram Sabha which are councils of all the voters at the village (i.e. Gram Sansad) and the GP level, respectively. In addition to these general bodies, villages often have a Gram Unnayan Samity (GUS) or a Village Development

\footnotetext{
${ }^{5}$ In total there are 8811 households in the 10 selected GPs. Of these, 34 percent are exclusively classified as farmers, 33 percent have small land holdings $(0.23$ acres $)$ and rely on farming and agricultural labour for their livelihood while the remainder (33 percent) are landless labourers. The corresponding figures at the district level are, farmers 32.6 percent, agricultural labourers are 37.1 percent and the remainder (30.3 percent) are landless (DHDR, 2007: p.18). The cropping intensity of the surveyed area is 139 percent which is close to the district average of 147 percent (DHDR, 2007: p. 5).
}

\footnotetext{
${ }^{6}$ Since the implementation of NREGS has picked-up gradually, since its launch in 2006, we did not include the initial years in the sample and focused on projects implemented during the financial years 2008-09 to 2010-11.

${ }^{7}$ We interviewed 23 village respondent groups. The average size of the VRG was 14 while the median size was 11. 75 percent of the respondents were male and except for 3 villages every VRG included at least one woman.
} 
Committee, which consists of elected local officials, members of NGOs and self-help groups amongst others. The role of the GUS is to ensure active participation of village residents in the implementation and distribution of the benefits of social programmes. Thus, the Gram Sabha, the Gram Sansad and the GUS are the institutions through which local needs maybe transmitted and through which people's participation in decision-making may be enhanced.

To identify the extent to which the selected projects match local needs we study the extent to which decisions regarding NREGS projects are taken by the Gram Sabha, Gram Sansad and the GUS as opposed to the executive (GP). To do so we divided project participation into four sub-components, that is, participation with regard to project type (the specific type of project to be undertaken), project site (the location of the project), project scale (the length or size of the project) and project design (technical design) and asked project-specific village respondent groups to identify the main body responsible for each of the four decisions. If there were doubts or the main organ responsible for decision-making could not be clearly identified, the VRG were asked to provide a narrative of the decision making process which was subsequently used to determine the main player in each of these decisions.

The analysis, presented in Table 4 shows two clear patterns. With regard to selection of project type and project location, for a majority of projects the key decision-making organs are the representative village bodies as opposed to the executive. This role is more dominant with regard to project location where the people's organizations were identified as the key decisionmaker in 79 percent of the cases as opposed to 54 percent in the case of project type selection. In contrast to these two elements of participation, the role of the community in determining the scale and design of the project is limited. In both cases, for 95 percent of the projects the executive along with concerned technical personnel (Nirman Sahayak/GP civil engineer) are the key decision-making players. Given the need for technical training, lower participation rates along these dimensions may be expected and may even be desirable. Notwithstanding the lower participation rate, in 56 percent of the projects (see Table 5) potential beneficiaries indicated that they participated in the non-technical aspects of project design by providing advice, suggestions and information on aspects such as the direction of the slope of a road or drain, information on the natural flow of water, the route of a road to be constructed, advice on the size of a pond to be dug and other suggestions of the same ilk. In about 60 percent of the cases where suggestions were offered the perception was that these had been sufficiently incorporated.

The overall patterns hide sharp differences across GPs. The data reveal that each GP has a dominant decision making mode and all projects within a GP are decided by that particular organ. For example, with regard to project type, the main player across all projects in Dhaban GP is the Gram Unnayan Samity similarly in Dahala GP all decisions on project type across all 
projects are reported to have been made by the Gram Panchayat. The analysis provided in Table 5 shows that there are no systematic differences with regard to community participation across zones but there are sharp differences across GPs. Community participation with regard to decision making on type and location seems to be substantial in 4 GPs (Dhaban, Dhanshimla, Fulmati, Khatragram) while it is less pronounced in the other GPs. Whether this has a bearing on project quality and maintenance is explored in the next section.

\section{Project quality, maintenance and sustainability}

The creation of durable assets which will serve as a basis for the sustained development of the rural economy can only be achieved by first ensuring quality during implementation of projects and thereafter proper maintenance of the assets. To ensure quality, technical standards have been set by the Ministry of Rural Development (MoRD). At the GP level the Nirman Sahayak is responsible for technical supervision of NREGS works and at the project level a supervisor is responsible for ensuring that quality standards are maintained. Finally, an important element is that the NREGA (as per Section 17) empowers Gram Sabhas to monitor the execution of works and to conduct social audits of all projects under the scheme. In West Bengal, the GUS has been authorized to monitor all development works taken up in their catchment areas. While the NREGS architecture related to project quality and monitoring seems to be well articulated, the act does not deal intensively with maintenance issues. While it does spell out that the State Government shall make rules for proper maintenance of public assets created under NREGS (Schedule I, Para. 5), so far, there are no specific rules regarding maintenance of the created assets. ${ }^{8}$ The Operational Guidelines of NREGA are also silent on this matter.

Our analysis shows that there is no formal maintenance mechanism in any of the GPs. According to the BDOs, it is up to the villagers to maintain the community assets for their own benefit. The heads of the GP (Pradhans) expressed their helplessness as they did not have funds earmarked for the purpose. Interactions with the VRG revealed that villagers felt a right to the benefits of the projects but their responsibility extended only to preventing project misuse and asking the GP to repair damages. However, in the case of 46 of the 82 projects, this vacuum appears to have been filled up by the GUS which is performing the function of a 'maintenance committee' as it is by default the committee charged with the task of ensuring the success of all village development projects. ${ }^{9}$

\footnotetext{
8 Maintenance is a concern for projects constructed on public land, which comprise the bulk of the projects. Maintenance of projects constructed on private land is the responsibility of the owner of the land. 9 In some projects in Barjora GP, traditional committees like "sholo-ana-committee" (meaning an all-representative
committee) is responsible for project maintenance.
} 
We assess the long-term development potential of NREGS by using perceptions of the initial project quality, current operational state and current physical conditions as markers of sustainability. With regard to initial project quality, the VRG were asked to provide a projectspecific assessment of whether in their opinion projects were 'well-made', with well-made described as projects which had a sound design, and used an appropriate combination of materials and labour. As shown in Table 4, 86 percent of the projects were rated as 'well-made' while the remainder were rated as adequately or badly made. In terms of their current operational state, according to the VRG the bulk of the projects ( 91 percent) may be rated in the two highest operational categories, fully or almost fully operational, with fully-operational described as working well and generating the intended benefits. To corroborate these views the authors and the enumerators assessed the current physical condition of the projects through onsite verification. This assessment was done by estimating the extent of damage compared to the total length or size of the project and recording it as a percentage of a project that is damaged. On average, the damage rate was estimated to be 8 percent and the bulk of the projects, about 77 percent, were rated to be in good physical condition. While this is considerably lower than the VRG provided figures on project operational conditions it is consistent with the VRG view that the bulk of the projects are delivering intended benefits. To explore this issue further we asked the VRG to assess a project's current performance, in terms of generating expected benefits, as compared to when it first started operating. In 32 percent of the case the projects were judged to be less beneficial than expected and at the same time in 37 percent of the projects the benefits were judged to be greater (see Table 4).

Finally, we presents estimates from a set of exploratory regressions where the current physical condition of the project (Table 6) and the current operational state of the project (Table 7) are regressed on various participation indicators and a set of additional controls. These regressions yield several points. First, regardless of the outcome under consideration, initial project quality has a strong bearing on reducing the extent of project damage and enhancing a project's operational status. Second, community participation in project selection also works in the same direction. Both these variables are associated with an 8 percent reduction in project damage, which is large considering that the overall project damage rate is about 8 percent. Third, other forms of participation such as involvement in selecting a project site and providing design suggestions do not appear to have a bearing on the outcomes. Similarly, the presence of a maintenance committee does not have a bearing on project damage. Prima facie this seems surprising but it may well be that if a project reflects local preferences then regardless of a maintenance committee it receives attention. This is consistent with the field experience. For example, in Khatragram GP, the GUS took the initiative and conducted community meetings 
and allocated responsibilities for project maintenance. Minor repair works were taken up by the villagers themselves while for major repairs the GUS took it up with the GP. In Barjora GP, a GP member took the initiative to repair minor damages with the help of local villagers and locally available materials. According to the VRG, in both places the villagers provided voluntary labour for maintenance as they perceived that the project was theirs and hence they repaired it for their own benefit.

\section{Concluding remarks}

This paper was motivated by the limited evidence on the quality and sustainability of the assets created through NREGS and the importance of such asset creation for the long-term goals that NREGS hopes to achieve. It dealt with two aspects. First, the extent to which the selected projects match local needs, as measured by community participation, and second the role of community participation in influencing the operational and physical condition of the projects. The study was based on a district-level representative survey of 82 completed projects in Bankura, one of 200 districts where NREGS was introduced in 2006.

While there are several reports about incomplete and non-existent projects and the poor quality of NREGS-built assets in other parts of the country, at least in Bankura we found that, except for one project the rest of the projects existed. According to the respondents, in 54 percent of the projects, citizen's forums such as the Gram Sabha, the Gram Sansad and the Gram Unnayan Samity played the key role in choosing the project type as opposed to the executive. The community also played a prominent role in selecting the project site in 79 percent of the cases. Community participation was far lower with regard to project design and scale (about 5 percent). With regard to initial project quality, the overwhelming perception (87 percent of the cases) was that the projects were well built and that they continue to provide benefits at the same or higher level as compared to when they were built (68 percent of the cases). Based on on-site verification of each of the projects we found that about 22 percent of the projects were moderately damaged while the remainder were in good physical condition.

While there is no formal maintenance system in place, we found that most of the projects were in reasonably good physical and operational state. At the same time there were variations across gram panchayats and exploratory regressions showed that initial project quality and the role of the community in selecting the project type play key roles in ensuring the physical condition and operational status of a project. While these estimates and the field experience drive home the importance of community participation in ensuring better project outcomes they also raise the question of what drives differences in participation across villages? The estimates presented here are in marked contrast to the picture evoked in existing studies and may well be specific to Bankura or to West Bengal, however, we wish to make two broader points. First, 
given the long-term aims of NREGS it is important to give greater research attention to assessing the quality and performance of NREGS-created infrastructure and second given the substantial variation in project outcomes across villages such assessments should be based on sound project-level empirical information. 


\section{References}

Action for food production (2009): "Infrastructure Development and Beyond: Exploring the Scope for Sustainable Livelihood Support under NREGA in Chainpur Block, Gumla District, Jharkhand" Available at http://www.nrega.net.

Ambasta, Pramathesh, P.S. Vijay Shankar and Mihir Shah (2008): "Two Years of NREGA: The Road Ahead", Economic and Political Weekly, 43(8): 41-50.

Bhatia, Bela and Jean Dreze (2006): "Employment Guarantee in Jharkhand: Ground Realities", Economic and Political Weekly, 41(29): 3198-3202.

Jha, R., S. Bhattacharya, R. Gaiha and S. Shankar (2009): ““Capture” of anti-poverty programs: An analysis of the National Rural Employment Guarantee Scheme in India", Journal of Asian Economics 20 (4): 456-464.

Institute of Applied Manpower Research (2008): "All-India Report on Evaluation of NREGA: A Survey of Twenty districts", http://planningcommission.gov.in/reports/genrep/rep NREGA 03-08-2009.pdf. Accessed on January 7, 2010.

Ministry of Rural Development (2008): “The National Rural Employment Guarantee Act 2005 (NREGA)-Operational Guidelines”, Ministry of Rural Development, Government of India, New Delhi.

Rai, Parshuram (2008): “The Great Job Robbery”, Available at http://www.cefsindia.org/reports/The\%20Great\%20Job\%20Robbery.pdf.

Ravi, Shamika and M. Engler (2009): "Workfare in Low-Income Countries: An Effective way to fight Poverty? The Case of NREGS in India". Available at http://ssrn.com/abstract $=1336837$.

UNDP (2007) 'District Human Development Report' Available at http://hdr.undp.org/en/reports/nationalreports/asiathepacific/india/Bankura india hdr 20 07.pdf, Accessed 04 August 2011. 
Table 1

Zonal distribution of sampled GPs

\begin{tabular}{|l|l|l|l|}
\hline & \multicolumn{1}{|c|}{ Zone I } & \multicolumn{1}{c|}{ Zone II } & \multicolumn{1}{c|}{ Zone III } \\
\hline $\begin{array}{l}\text { Sampled GPs } \\
\text { Number of } \\
\text { projects) }\end{array}$ & $\begin{array}{l}\text { Dahala (10) } \\
\text { Dhaban (13) } \\
\text { Khatragram (6) } \\
\text { Ramchandrapur (4) }\end{array}$ & $\begin{array}{l}\text { Barjora (12) } \\
\text { Fulmati (8) } \\
\text { Khandari (8) }\end{array}$ & $\begin{array}{l}\text { Dhanshimla (5) } \\
\text { Jagannathpur (8) } \\
\text { Maynapur (8) }\end{array}$ \\
\hline Project type & Rural connectivity & $\begin{array}{l}\text { Water conservation/water } \\
\text { harvesting }\end{array}$ & $\begin{array}{l}\text { Renovation of } \\
\text { traditional bodies }\end{array}$ \\
\hline $\begin{array}{l}\text { District (in \%) } \\
\text { Sample (in \%) }\end{array}$ & 32 & 32 & \multicolumn{1}{c|}{24} \\
\hline
\end{tabular}

Table 2

Community Participation

\begin{tabular}{|l|c|c|c|c|c|}
\hline & \multicolumn{5}{|c|}{ Main player in each decision } \\
& \multicolumn{5}{|c|}{ (\% of total) } \\
Variable & $\begin{array}{c}\text { Gram } \\
\text { Panchayat }\end{array}$ & $\begin{array}{c}\text { Gram } \\
\text { Panchayat } \\
\text { Member }\end{array}$ & Gram Sabha & Gram Sansad & $\begin{array}{c}\text { Gram } \\
\text { Samity }\end{array}$ \\
\hline Selection of project type & 31 & 7 & 12 & 5 & 27 \\
& $(38)$ & $(8)$ & $(15)$ & $(6)$ & $(33)$ \\
\hline Selection of site & 1 & 16 & 0 & 18 & 47 \\
& $(1)$ & $(20)$ & $(0)$ & $(22)$ & $(57)$ \\
\hline Determining scale of project & 77 & 0 & 0 & 2 & 3 \\
& $(94)$ & $(0)$ & $(0)$ & $(2)$ & $(4)$ \\
\hline Determining project design* & 78 & 0 & 0 & 0 & 0 \\
& $(95)$ & $(0)$ & $(0)$ & $(0)$ & $(0)$ \\
\hline
\end{tabular}

Notes: $* 5$ percent of the projects were designed by non-GP level government agencies

Table 3

\begin{tabular}{|c|c|}
\hline Project design suggestions & $\begin{array}{c}\mathrm{N} \\
(\%)\end{array}$ \\
\hline Suggestions made & $\begin{array}{c}46 \\
(56)\end{array}$ \\
\hline Suggestions not included & $\begin{array}{c}3 \\
(6) \\
\end{array}$ \\
\hline Suggestions included to some extent & $\begin{array}{c}16 \\
(35)\end{array}$ \\
\hline Suggestions included & $\begin{array}{c}27 \\
(59) \\
\end{array}$ \\
\hline
\end{tabular}


Table 4

\begin{tabular}{|l|c|}
\hline Project attributes & $N$ \\
& $(\%)$ \\
\hline Initial project quality & 71 \\
Well made & $(87)$ \\
\hline Current operational status & 43 \\
Fully operational & $(52)$ \\
& 32 \\
More or less operational & $(39)$ \\
& 6 \\
Partially operational & $(7)$ \\
& 1 \\
Non-operational & $(1.22)$ \\
\hline Current physical condition & 26 \\
Undamaged & $(32)$ \\
Minimal damage & 37 \\
Moderate damage & $(45)$ \\
& 17 \\
Severely damaged & $(21)$ \\
& 1 \\
& $(1.22)$ \\
\hline Project performance in terms of expected benefits & \\
(as compared to benefits at time project became operational) & 23 \\
Much better & $(28)$ \\
Slightly better & 14 \\
Same & $(17)$ \\
Less & 19 \\
& $(23)$ \\
& 26 \\
& $(32)$ \\
\hline
\end{tabular}

Table 5

Participation and project attributes across GPs

\begin{tabular}{|l|l|l|c|c|c|}
\hline Zone and GP & \multicolumn{1}{|c|}{$\begin{array}{c}\text { Selection of project } \\
\text { type }\end{array}$} & Selection of site & $\begin{array}{c}\text { Moderate } \\
\text { damage } \\
(\%)\end{array}$ & $\begin{array}{c}\text { Percent of } \\
\text { project that } \\
\text { is damaged }\end{array}$ & $\begin{array}{c}\text { Expected } \\
\text { benefits less } \\
\text { than at start } \\
(\%)\end{array}$ \\
\hline $\begin{array}{l}\text { Zone I } \\
\text { Dahala }\end{array}$ & Gram Panchayat & Gram Unnayan Samity & 0 & 5 & 30 \\
Dhaban & Gram Unnayan Samity & Gram Unnayan Samity & 54 & 16 & 31 \\
Khatragram & Gram Unnayan Samity & Gram Unnayan Samity & 0 & 8 & 0 \\
Ramchandrapur & Gram Panchayat & Gram Panchayat & 0 & 19 & 0 \\
Zone II & Gram Sabha & Gram Panchayat & 0 & 7.5 & 67 \\
Barjora & Gram Unnayan Samity & Gram Unnayan Samity & 25 & 3 & 0 \\
Fulmati & Gram Panchayat & Gram Sansad & 75 & 0 & 75 \\
Khandari & Gram Sansad & Gram Sansad & 0 & 4.25 & 20 \\
Zone III & Gram Panchayat & Gram Unnayan Samity & 37.5 & 5 & 25 \\
Dhanshimla & Gram Panchayat & Gram Sansad & 12.5 & 10 & 25 \\
Jagannathpur & & & \\
Maynapur & \multicolumn{2}{|l}{}
\end{tabular}


Table 6

Project damage and participation - OLS estimates

(Absolute t-statistic)

\begin{tabular}{|c|c|c|c|}
\hline Variable & (1) & $(2)$ & (3) \\
\hline $\begin{array}{l}\text { Project quality } \\
\text { (well made }=1 ; 0 \text { otherwise) }\end{array}$ & $\begin{array}{c}-7.67^{* *} \\
(2.30)\end{array}$ & $\begin{array}{c}-7.82^{* *} \\
(2.36)\end{array}$ & $\begin{array}{l}-9.08^{* *} \\
(2.33)\end{array}$ \\
\hline $\begin{array}{l}\text { Selection of project type } \\
\text { (Gram Sansad/Gram Sabha/GUS decides }=1 ; 0 \text { otherwise) }\end{array}$ & $\begin{array}{l}-7.69 * \\
(2.71)\end{array}$ & $\begin{array}{l}-8.84 * \\
(3.01)\end{array}$ & $\begin{array}{l}-8.22 * * \\
(2.38)\end{array}$ \\
\hline $\begin{array}{l}\text { Selection of site } \\
\text { (Gram Sansad/Gram Sabha/GUS decides }=1 ; 0 \text { otherwise) }\end{array}$ & $\begin{array}{c}4.07 \\
(1.09)\end{array}$ & $\begin{array}{c}5.63 \\
(1.45)\end{array}$ & $\begin{array}{l}7.36 \\
(1.44)\end{array}$ \\
\hline $\begin{array}{l}\text { Design suggestions made }=1 \\
\text { Maintenance committee exists }=1\end{array}$ & $\begin{array}{c}0.141 \\
(0.05) \\
.\end{array}$ & $\begin{array}{c}-0.269 \\
(0.09) \\
3.80 \\
(1.39)\end{array}$ & $\begin{array}{c}0.619 \\
(0.19) \\
4.31 \\
(1.42)\end{array}$ \\
\hline $\begin{array}{l}N \\
R^{2}\end{array}$ & 82 & 82 & 72 \\
\hline
\end{tabular}

Notes: Dependent variable is percentage of project in damaged state. All specifications include project type, zone where project is located, number of households in village, number of retail shops and non-farming enterprises, distance of village from nearest market. In addition, estimates in column (3) include project age. *, **, *** statistically significant at 1,5 and 10 percent, respectively.

Table 7

Project operational status and participation - OLS estimates (Absolute t-statistic)

\begin{tabular}{|c|c|c|c|}
\hline Variable & (1) & (2) & (3) \\
\hline $\begin{array}{l}\text { Project quality } \\
\text { (well made }=1 ; 0 \text { otherwise) }\end{array}$ & $\begin{array}{c}0.834^{*} \\
(4.74)\end{array}$ & $\begin{array}{c}0.842^{*} \\
(4.84)\end{array}$ & $\begin{array}{l}0.829^{*} \\
(4.29)\end{array}$ \\
\hline $\begin{array}{l}\text { Selection of project type } \\
\text { (Gram Sansad/Gram Sabha/GUS decides }=1 ; 0 \text { otherwise) }\end{array}$ & $\begin{array}{c}0.321 * * \\
(2.15)\end{array}$ & $\begin{array}{c}0.387 * * \\
(2.51)\end{array}$ & $\begin{array}{l}0.259 \\
(1.51)\end{array}$ \\
\hline $\begin{array}{l}\text { Selection of site } \\
\text { (Gram Sansad/Gram Sabha/GUS decides }=1 ; 0 \text { otherwise) }\end{array}$ & $\begin{array}{r}-0.231 \\
(1.17)\end{array}$ & $\begin{array}{l}0.321 \\
(1.57)\end{array}$ & $\begin{array}{l}-0.225 \\
(0.89)\end{array}$ \\
\hline Design suggestions made $=1$ & $\begin{array}{c}-0.107 \\
(0.71)\end{array}$ & $\begin{array}{c}-0.083 \\
(0.56)\end{array}$ & $\begin{array}{r}-0.049 \\
(0.31)\end{array}$ \\
\hline Maintenance committee exists $=1$ & . & $\begin{array}{c}-0.219 \\
(1.52)\end{array}$ & $\begin{array}{r}-0.197 \\
(1.31)\end{array}$ \\
\hline$N$ & 82 & 82 & 72 \\
\hline
\end{tabular}

Notes: Dependent variable is project is fully operational $=1,0$ otherwise. All specifications include project type, zone where project is located, number of households in village, number of retail shops and non-farming enterprises, distance of village from nearest market. In addition, estimates in column (3) include project age. *, **, *** statistically significant at 1,5 and 10 percent, respectively. 